\title{
The International Lithosphere Program
}

The International Lithosphere Program is based on the perception by the community of solid Earth scientists that major advances at the forefront of the investigation of the lithosphere can be achieved only as the result of a joint venture of the various earth science disciplines in international cooperation. This cooperation must incorporate the developing countries and pool the expertise of academia and industry in the investigation of the lithosphere's evolution, structure, composition, dynamics, resources, and hazards.

The earth sciences continue to grow together. We are beginning to understand the Earth as a system. We have new tools at our disposal that allow us to observe aspects of our planet that we could not have imagined a decade ago, and this technological development is very rapid.

At the same time, a new gap is developing among the earth science disciplines. The acceleration of technological developments in the various disciplines is so fast that neighboring disciplines are not aware of these developments or cannot grasp their implications, which are vital for the future investigation of our planet.

\section{Introduction}

The Inter-Union Commission on the Lithosphere (ICL) was founded in 1980 by the International Council of Scientific Unions (ICSU) at the request of the International Union of Geodesy and Geophysics (IUGG) and the International Union of Geological Sciences (IUGS), the two Unions in the solid Earth sciences. The ICL has been directing the International Lithosphere Program (ILP) since 1981. The ILP is in the tradition of the earlier Upper Mantle Project and the Geodynamics Project.

The ICL is charged to investigate the lithosphere and to give special attention to the following aspects:

- Origin and evolution of the lithosphere prior to $200 \mathrm{Mega-annum}$ (Ma, $10^{6}$ years)

- Structure, physical properties, composition, and dynamics of the lithosphere with special attention to the continents and their margins

- Difference between the oceanic and continental lithosphere

- Assessment, prediction, and mitigation of hazards, both natural hazards and those induced by human activities

- Assessment of the Earth's resources
The successful pursuit of these assignments requires the incorporation of the following guidelines of operation:

- Cooperation among various disciplines, namely geologists, geophysicists, geochemists, and geodesists

- International cooperation because most of the problems are global and because earth sciences are not provincial sciences

- Strengthening of communication and cooperation between geoscientists in basic and applied research

- Strengthening of the earth sciences in the developing countries

\section{ILP special projects}

The ILP is operating presently through six working groups (WG) and seven coordinating committees (CC). After a restructuring of the ILP in 1985 and 1986, all WGs (table 1) and CCs (table 2) were encouraged to define special projects that they regarded as frontier research in their field of responsibility and that they wanted to pursue vigorously for the coming years. This led to the formation during the past 3 years of about 40 subgroups called task groups, teams, or subcommittees.

Table 1. - ILP special projects in working groups (WG)

\begin{tabular}{|c|c|}
\hline Number & Project (coordinator) \\
\hline WG-I & $\begin{array}{l}\text { Great earthquakes of the late Holocene (R. Yeats). } \\
\text { World map of active faults (V.G. Trifonov). } \\
\text { Application of space geodesy to global seismic hazards (R. Bilham, } \\
\text { S. Zerbini). }\end{array}$ \\
\hline WG-2a & $\begin{array}{l}\text { Subduction-related magmatism (D.H. Abott). } \\
\text { Granite-greenstone terranes (K.D. Card). } \\
\text { Paleocontinental reconstruction (P. Hoffman). }\end{array}$ \\
\hline $\begin{array}{l}\text { WG-2b } \\
\text { WG-2c }\end{array}$ & $\begin{array}{l}\text { Paleomap of continental reconstruction (C. Scotese, } \mathrm{L} \text {. Zonenshain). } \\
\text { Composition of the lower continental crust (with } \mathrm{WG}-6 ; \mathrm{N} \text {. Arndt). } \\
\text { Composition of granitoids of different ages. } \\
\text { Global map of } \mathrm{Nd} \text { model ages and U-Pb zircon ages. }\end{array}$ \\
\hline WG-3. & $\begin{array}{l}\text { Geodynamics and deep internal processes (H. Neugebauer). } \\
\text { Basin analysis (A.B. Watts). } \\
\text { Isostasy (G.D. Karner). } \\
\text { Tectonics (J. Letouzey). } \\
\text { Refraction and deep reflection seismic (with WG-6; D.J. Blundell), } \\
\text { Igenous activity (R. Altherr). } \\
\text { World Stress Map (M.L. Zoback). }\end{array}$ \\
\hline$W G-4$. & $\begin{array}{l}\text { Processes at midoceanic ridges. } \\
\text { Interaction between Ocean Drilling Program and ICL. } \\
\text { Global geoscience data base relevant to the oceanic lithosphere. } \\
\text { Geotraverses as applied to ocean basins. }\end{array}$ \\
\hline WG-5. & $\begin{array}{l}\text { Arctic Ocean deep sea drilling. } \\
\text { Paleoenvironmental contributions to International Geosphere- } \\
\text { Biosphere Programme (IGBP). }\end{array}$ \\
\hline WG -6 & $\begin{array}{l}\text { Reflection survey of the continental crust. } \\
\text { Lower crust (with WG-2c). } \\
\text { World map of Moho topography (R. Meissner). } \\
\text { Diamonds in the lithosphere (N. Sobolev). }\end{array}$ \\
\hline
\end{tabular}


Table 2. - ILP special projects in coordinating committees (CC)

\begin{tabular}{|c|c|}
\hline Number & Project (coordinator) \\
\hline \multirow[t]{4}{*}{$\mathrm{CC}-1$} & Paleoflood hydrology (V.R. Baker) \\
\hline & $\begin{array}{l}\text { Multidisciplinary studies of selected high-risk volcanoes with } \\
\text { emphasis on collateral hazards (G. Heiken) }\end{array}$ \\
\hline & $\begin{array}{l}\text { Probabilistic approach to geological hazards (K.J. Coppersmith, } \\
\text { C.G. Newhall) }\end{array}$ \\
\hline & Landslides of the world (D.M. Cruden, D. Keefer) \\
\hline \multirow[t]{3}{*}{$\mathrm{CC}-2$} & Deep seismic and sedimentary basins (C. Bois) \\
\hline & Heat sources in time and space (H.J. Neugebauer) \\
\hline & Multisensor data integration for resource assessment (G.W. Hill) \\
\hline \multirow[t]{4}{*}{$\mathrm{CC}-3$} & $\begin{array}{l}\text { Seismology and earth sciences in Africa (with International Asso- } \\
\text { ciation of Seismology and Physics of the Earth's Interior } \\
\text { (IASPEI/Unesco) }\end{array}$ \\
\hline & Global Geoscience Transects in developing countries \\
\hline & $\begin{array}{l}\text { Effort to distribute compact discs with read-only memory storage } \\
\text { (CD-ROMS) in developing countries (with CC-5) }\end{array}$ \\
\hline & Earthquake hazard to urban population in developing countries \\
\hline \multirow[t]{2}{*}{$\mathrm{CC}-4$} & $\begin{array}{l}\text { International symposiums and workshops for exchange of scientific } \\
\text { and technological expertise in continental drilling }\end{array}$ \\
\hline & Definition of drilling goals and sites in an international framework \\
\hline \multirow[t]{3}{*}{$\mathrm{CC}-5$} & $\begin{array}{l}\text { Directory of "Data Sources for Lithospheric Investigations" with } \\
\text { World Data Center A }\end{array}$ \\
\hline & $\begin{array}{l}\text { Distribution of compact disc technology in developing countries } \\
\text { (with CC-3, joint venture with World Data Centers of the } \\
\text { International Council of Scientific Unions) }\end{array}$ \\
\hline & $\begin{array}{l}\text { Neotectonic regionalization of the globe and identification of } \\
\text { earthquake-prone areas (with WG-1) }\end{array}$ \\
\hline \multirow[t]{3}{*}{$\mathrm{CC}-6 / 1-3}$. & Himalayan region (Ma-Xinghuan, R.A. Khan Tahirkheli) \\
\hline & Arctic region (G.L. Johnson) \\
\hline & Andean region (V.A. Ramos, A. Bermudez) \\
\hline $\mathrm{CC}-7$ & Global Geoscience Transects: GGT (J. Monger, H.-J. Goetze) \\
\hline
\end{tabular}

\section{ILP highlights and key projects}

From the beginning, the ILP has endeavored to reach its goals not only by arranging symposiums and workshops at large earth science Congresses and on special occasions but also by pursuing a number of well-defined, key projects. A key project is meant to serve as a critical test of an important hypothesis, to close crucial gaps in our knowledge, or even to open new doors to our understanding of the lithosphere. The announcements of such key projects provide standards for the initiation of regional and national programs that contribute to the ILP. Also, existing programs that fall under the definition of key projects are made known to and beyond the ILP community.

In this paper, some of these key projects will be discussed, the ones that are most typical of the ILP, because they require the intense linkage of various disciplines and international cooperation, the involvement of developing countries, and (or) the integration of applied geosciences. They fall into two fields, the exploration and the dynamics of the lithosphere (table 3 ). The ILP does not claim that all of these research programs have been started within the ILP. However, it takes responsibility for the fast international communication within these important projects

The ILP does not have the resources to finance even a small fraction of the very high costs of applying modern, sophisticated technology to the problems of the evolution and the dynamics of the lithosphere. Nonetheless, it has a fundamental, international influence on the rate and direction of research on the lithosphere. This influence results from the fact that the ILP is effective in stimulating and critically evaluating research through the sharing of information and ideas among different scientific disciplines and regional and national groups.
Table 3.-ILP key projects on the exploration and the dynamics of the lithosphere

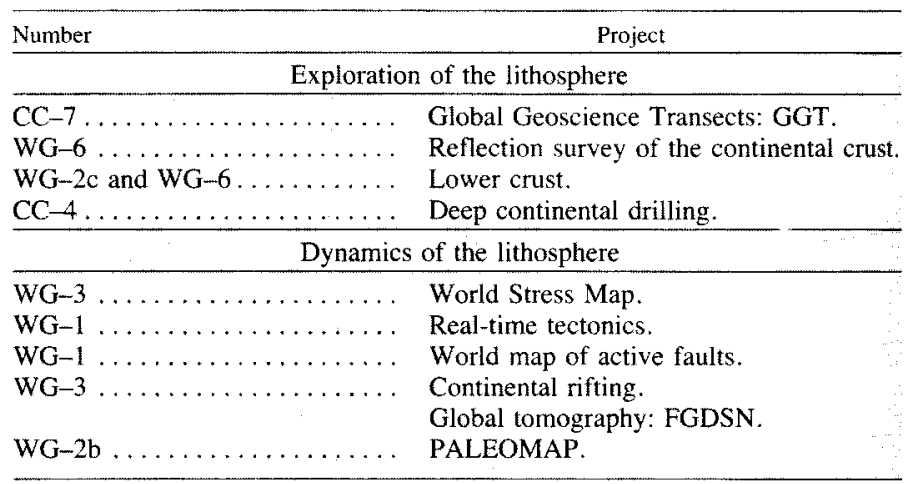

\section{Exploration of the lithosphere}

One of the outstanding frontiers of the earth sciences is the exploration of the lithosphere in a manner and intensity that start to become comparable with the exploration of the sediments for hydrocarbon deposits. Today, at least, the same tools (seismic-reflection surveys and deep drilling) are used.

\section{Global Geoscience Transects project}

The Global Geoscience Transects (GGT) project is modeled after the Decade of North American Geology Continent-Ocean Transect project. It represents the very spirit of the ILP because it comprises many of the fundamental principals on which ILP is built (Monger, 1986, 1989). Its goal is to construct lithospheric transects, mainly crustal cross sections through crucial geologic and tectonic features, such as mountain belts, grabens, sedimentary basins, and hazardous regions prone to the disastrous activities of earthquakes and volcanoes, in order to allow direct comparisons.

All of the available geological, geophysical, and geochemical data are assembled at an equal scale and with an identical color code in order to make possible global comparisons of similar structures and to display as well as possible the nature and evolution of the Earth's lithosphere. These transects allow the testing of hypotheses based on structure and on physical and compositional properties by using quantitative modeling and model improvements where a mismatch of observed and calculated data occurs. Wherever feasible, transects should be built on a digital data base. Transects also should form the basis for more detailed surveys (depth range of faults, the roots of volcanoes) made by using various geophysical methods (high-resolution seismic tomography, high-precision hypocenter determination, electromagnetic deep probing, geochemical surveying, $\mathrm{He}^{3} / \mathrm{He}^{4}$ distributions), as well as the determination of recent crustal movements detected by using satellite and ground-based methods.

Under the leadership of Jim Monger (Canada), the GGT has expanded as a truly international and interdisciplinary research effort in its coverage of the globe by the formation of dedicated teams (fig. 1). Special GGT meetings have been held in several parts of the world in order to develop and coordinate the work of the regional groups. Scientists from developing countries are participating actively in the program and are contributing their own expertise.

In South America, a transect through the Andes (AntofagastaCordillera Occidental-Salta-Chaco) has been presented not only in digital form but has been tested against gravity as well (Goetze and others, 1990; Reutter and others, 1988). The European Geotraverse (Galson and Mueller, 1987) from Cape North to the Mediterranean is a 


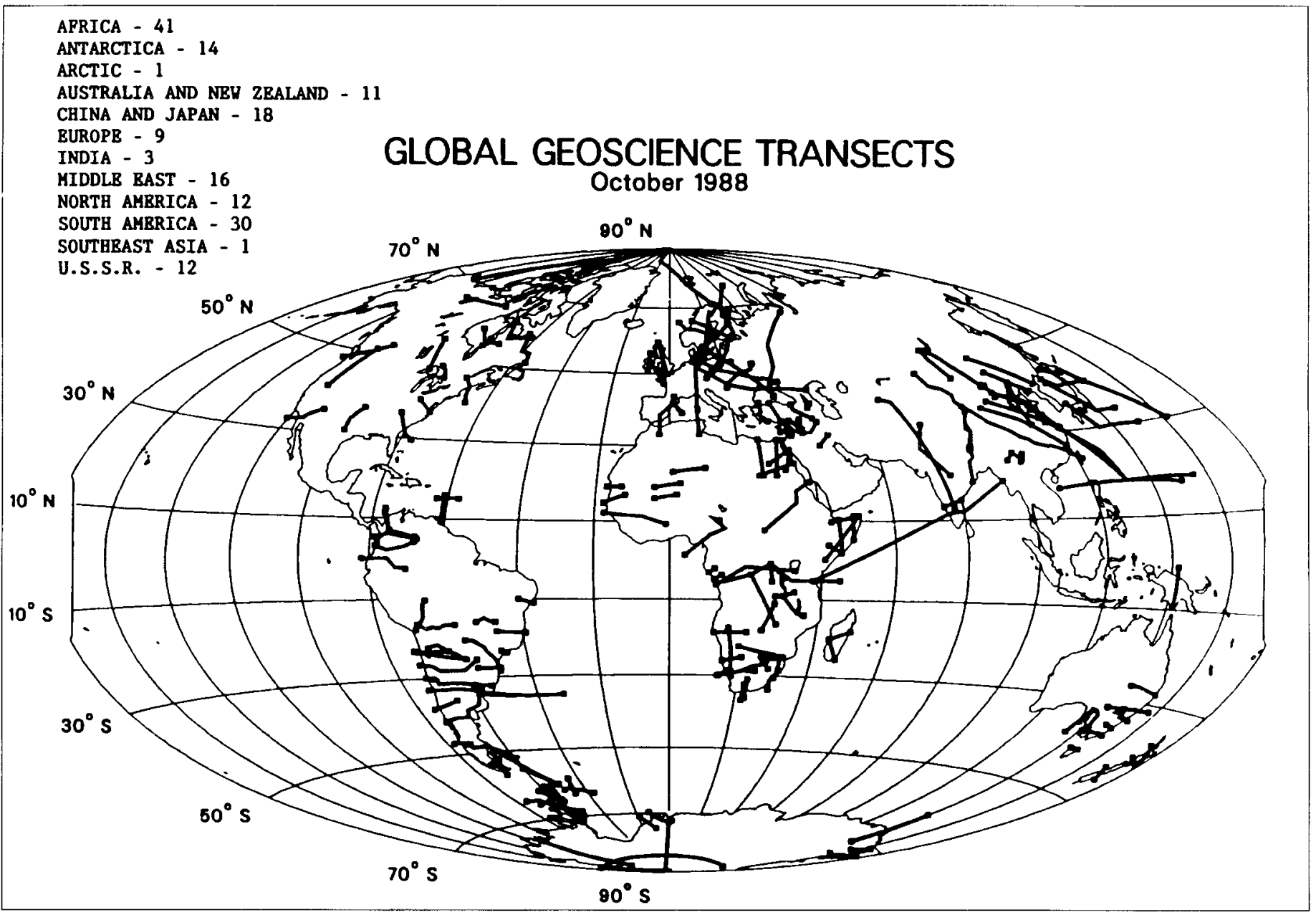

Figure 1.-World map of the ILP's Global Geoscience Transects project showing the number of transects as of October 1988. Taken from Monger (1989).

model for the plan of the new geotransect EUROPROBE that spans from the Atlantic Ocean to the Ural Mountains and connects two deep continental drill holes (KTB-Oberpfalz in FRG and Uralskayar in USSR). This should relate the young, thin, and hot crust of Western Europe to the old, thick, and cold platform crust of Eastern Europe. The transect of the future (both three-dimensional and digital) was started in the Quebec-Maine-Gulf of Maine area (Stewart, 1989; Stewart and others, 1989).

\section{Reflection survey of the continental crust and lower crust}

Continentwide reflection measurements have revealed the fine structure and architecture of the crystalline earth crust by the use of the most advanced technology developed in the oil industry. These measurements have even started to reach into the subcrustal lithosphere. Reflection programs in many countries (ACORP in Australia, BIRPS in UK, CALCRUST in USA, COCORP in USA, DEKORP in FRG, ECORS in France, and LITHOPROBE in Canada) have drastically changed our understanding of the continental crust (Oliver, 1986).

The role of the lower crust (Percival and Berry, 1987) in continental tectonics was recognized by the introduction of a lower crust key project of the ILP. This project requires truly interdisciplinary and international cooperation in the fields of geophysics, seismology, geo- chemistry, petrology, geology, and geodesy. The physical properties, composition, and temperature history of the lower crust are important in the development of sedimentary basins and continental grabens.

The Earth's crust is characterized by a surprisingly transparent upper part containing bright spots and a highly reflective lower part containing lamellas. Klemperer (1987) established an important correlation between continental heat flow and the seismic reflectivity of the lower crust. In addition, the determination of earthquake foci, the analysis of xenoliths, fluid inclusions, and stress distribution are all important tools for the future investigation of the lower crust. Integrated seismic experiments using wide-angle refraction and nearvertical reflection surveys in combination with $P$ and $S$ waves allow the determination of physical parameters and also narrow the range of possible compositions (Holbrook and others, 1988; Lueschen and others, 1987; Wenzel and others, 1987).

During the ILP, the model of the lower crust has received new input from several disciplines and subdisciplines. A granulite data base was established to narrow down the composition of the lower continental crust by compiling the results of 1,700 analyses of rocks from granulite-facies terranes and by comparing these with similar data from lower crustal xenoliths. The average composition of granulite terranes is clearly more felsic than that of granulite xenoliths (Rudnick and others, 1988). 
While the Earth's crust is gradually gaining contours and colors from reflection surveys, the upper mantle part of the lithosphere is still regarded as the domain of the friends of a horizontally homogeneous Earth. Reflections to about 30-second (s) Two-Way-Traveltime (TWT) (fig. 2) were detected and explored systematically north of Scotland by the BIRPS group (McGeary and Warner, 1985). This discovery, although established for the first time by the use of marine seismic studies, has been confirmed also on land. In Hungary (K. Posgay, oral communication), a systematic search for reflections from the upper mantle was very successful.

\section{Deep continental drilling}

A continental scientific drilling program is needed as part of the integrated studies of the Earth's crust in order to provide data on the composition and physical state of the Earth's crust and to test the validity of fundamental concepts based on extensive laboratory, field, and theoretical studies. Continental drilling is another field of frontier research that requires broad interdisciplinary and international cooperation. The goals of this drilling can be summarized under the following headings: earthquakes and crustal deformation, volcanic and magmatic processes, evolution of continental lithosphere, basin evolution and hydrocarbon resources, mineral resources, thermal regimes and geothermal energy, calibration of crustal geophysics, role of fluids in crustal processes, and lithospheric dynamics (Zoback, Elders, and others, 1988).

The tangible goals at the KTB site in the Oberpfalz in Bavaria, FRG, include the depth distribution of both temperature and stress, and the hole will reach the brittle-ductile transition zone. Another target here is the study of the nature of crystalline reflectors. We are using the most advanced imaging tools developed in the petroleum industry for sedimentary layers in order to provide close interaction between seismic reflection and control by drilling. Many thousands of kilome- ters of reflection profiles have been obtained for the crystalline crust without corresponding testing and development in the crystalline environment. Surprises already have come from the $4-\mathrm{km}$ pilot hole of the KTB project. The temperature prediction from the presite survey appeared to be highly unreliable because the conductive model of heat transport was insufficient and convection processes are difficult to predict. Graphite was encountered on foliation planes, and the pilot hole was drilled into an electrically conductive body.

The Cajon Pass project (Zoback, Silver, and others, 1988) has begun to solve the heat flow and stress paradox at the San Andreas fault, California, USA, as well as to provide a new understanding of a low-strength fault (Zoback and others, 1987). This will have implications not only for earthquake mechanisms and predictions but also for tectonic processes at major faults. The study of major active faults is another key project of the ILP that is starting under the leadership of V.G. Trifonov (USSR).

\section{Dynamics of the lithosphere}

New global and regional data bases that are directly or indirectly related to the dynamics of the lithosphere are developing rapidly. The World Stress Map and the application of space geodetic methods are the most important examples.

\section{World Stress Map project}

The World Stress Map project, under the leadership of Mary Lou Zoback (USA), is establishing a new, fundamental global data base of modern tectonic stresses in the crust (primary orientation and magnitude where available). This is comparable in importance to world maps of geoid undulations, gravity, or heat flow. The intraplate-stress data

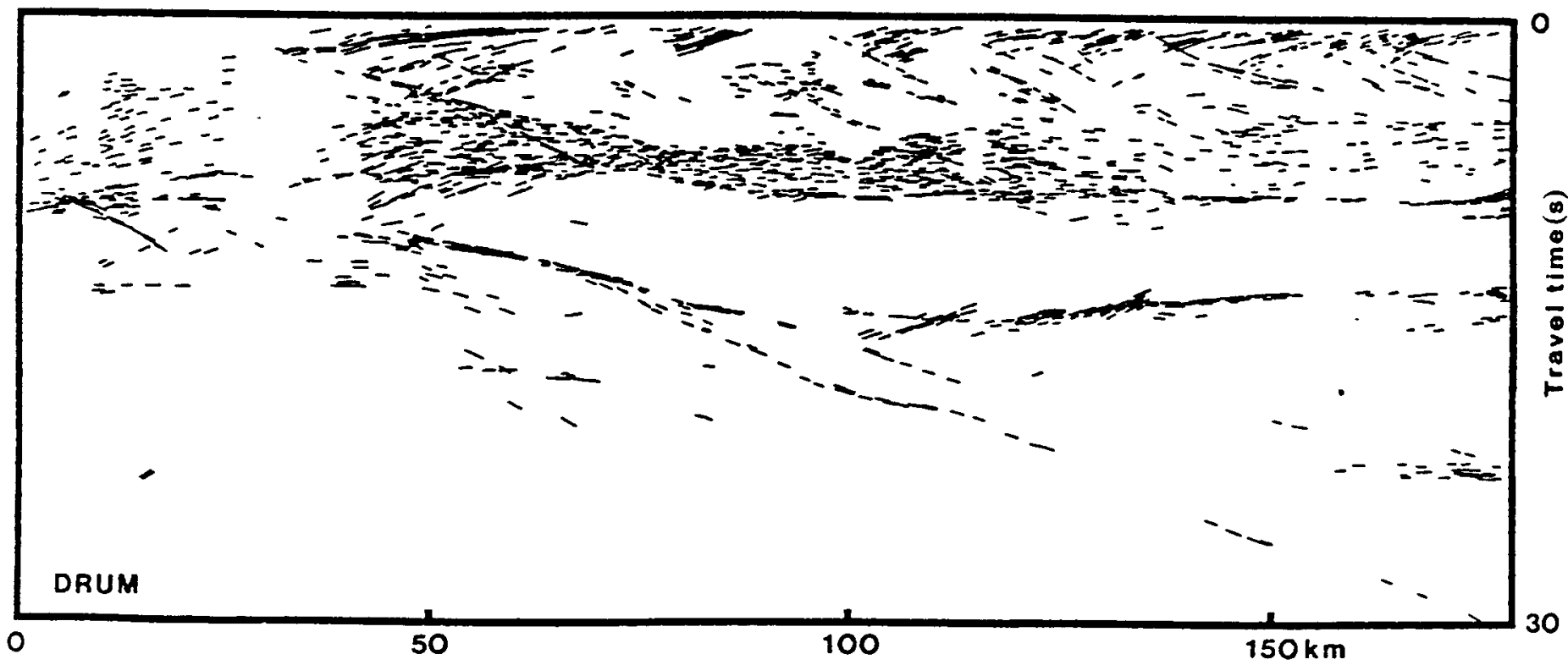

Figure 2.-30-s DRUM profile of the BIRPS group at the Outer Isle fault north of Scotland. A line drawing, the section is in TWT and is true scale at a velocity of $5 \mathrm{~km} / \mathrm{s}$. Within the mantle are three major features: the east-dipping Flannan thrust, a subhorizontal reflector at 13-15s between 80 and $180 \mathrm{~km}$, and the 15-km-wide zone of horizontal reflections at $23 \mathrm{~s}$ at the east end of the section. Taken from McGeary and Warner (1985). 


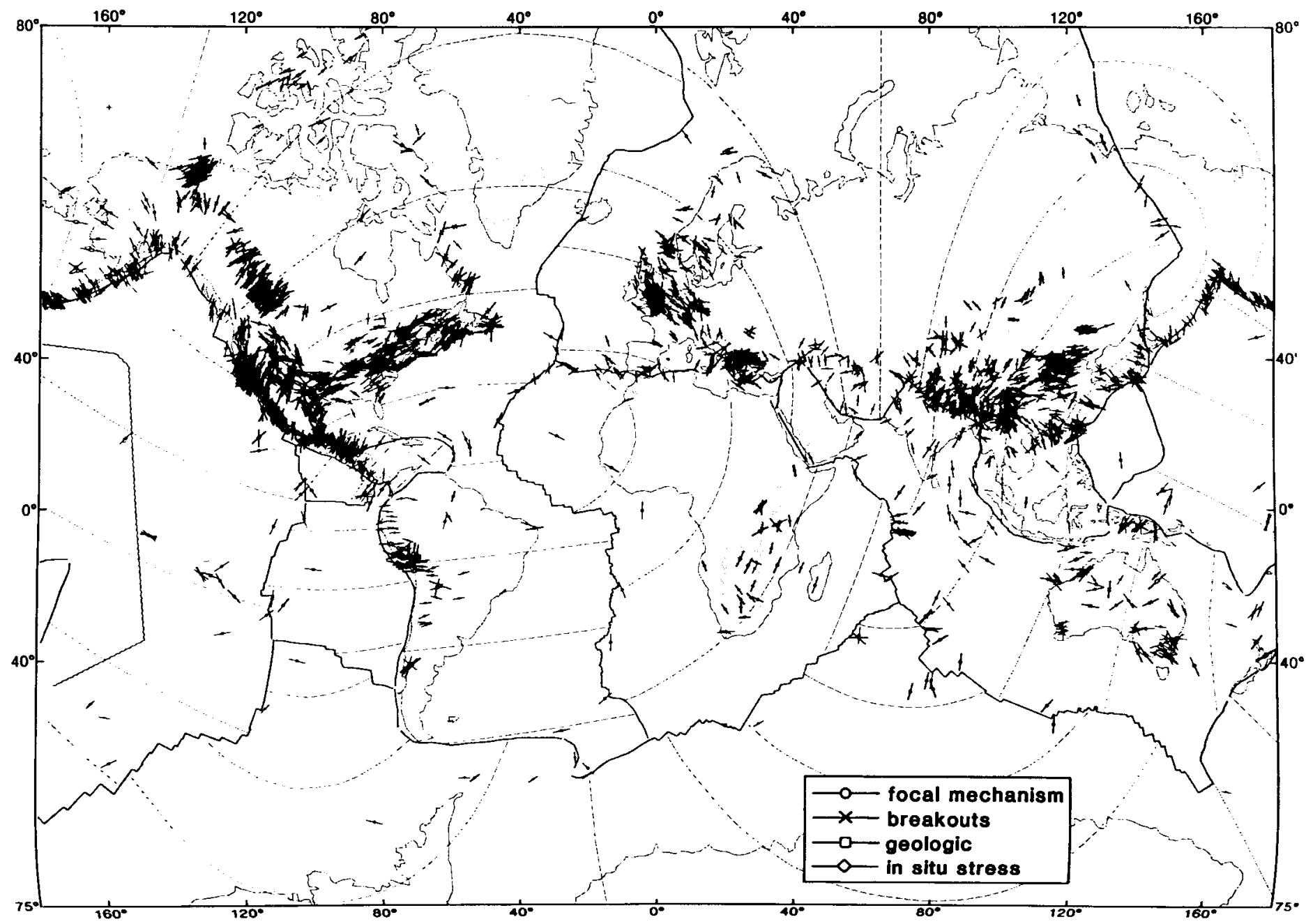

Figure 3. - World Stress Map taken from Zoback and others (1989).

can be used in conjunction with global plate-motion data in order to further our understanding and modeling of the dynamic processes driving plate tectonics.

One very important result of the World Stress Map project (fig. 3; Zoback and others, 1989) is the recognition of stress provinces and the diffuse border zones in midcontinental regions. In large part, the trajectories of the maximum horizontal stress directions are parallel to the trajectories of plate movements (Minster and Jordan, 1978). How are the various types of large active faults affecting the pattern of stress trajectories?

A global investigation of the relationship between intraplate seismicity and stress patterns is needed in order to provide critical input for the important problem of evaluating earthquake hazards in intraplate regions. The data base, established in close cooperation with the petroleum industry, will provide practical information for reservoir engineering and civil engineering, as well as identification of high- and low-strength faults.

\section{World Strain Map and real-time tectonics}

One of the highlights of modern space geodetic methods is the overall verification of the direction and magnitude of plate motions (Smith and others, 1985) as derived from geological and geophysical data about the past 200 million years (m.y.) (Minster and Jordan, 1978). Today, the earth sciences are moving rapidly toward establishing deformation not only of the plate configuration but also of the interiors of plates in a time span of a few years, that is, deformation practically in real time.

One example of real-time deformation is the determination of the direction of maximum contraction and its magnitude in Western Europe using Satellite Laser Ranging data during 1984, 1985, and 1986 at six stations (fig. 4; Katsambalos and others, 1989). The derived direction of maximum contraction is about N. $10^{\circ}-20^{\circ}$ E. in Western Europe, but this is in marked disagreement with the northwestsoutheast orientation for the maximum compressional stress in the same region as determined in the World Stress Map for Europe. Discrepancies between stress and strain tensors are highly indicative of the nature of plates. Strong deviation between stress and strain tensors (direction of the principal axes deviates by about $60^{\circ}$ ) cannot be explained by elastic anisotrophy, but instead a block structured medium with freely moving boundaries must be considered. Such a discrepancy between the direction of principal stress and the strain (if not produced by measurement errors or glacial rebound) indicates a highly nonlinear medium, such as a block medium.

Geodetic positioning by the use of Global Positioning System (GPS) stations reaches such an accuracy that it becomes a tool in earthquake prediction (fig. 5; Bilham, 1988; Bilham and others, 1989). At its annual meeting in Belém, Brazil, in 1988, the ICL passed the 


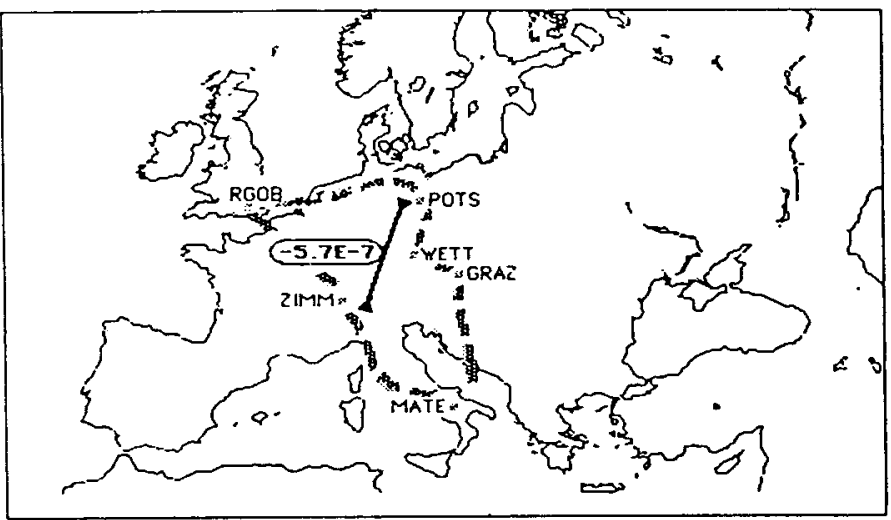

A, strain interpretation of the $1985-1984$

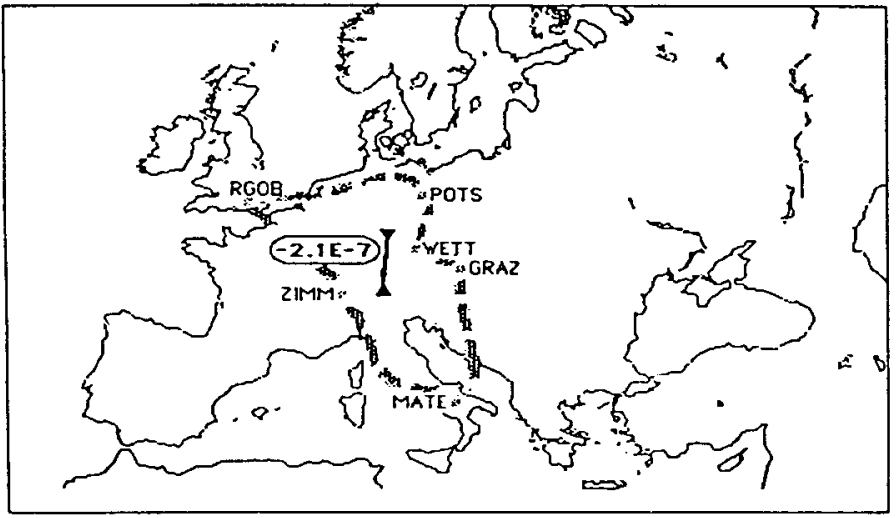

B, Strain INTERPRETATION OF THE (1986-1985)

Figure 4.-Strain interpretation in Western Europe showing the 1985-1984 (A) and 1986-1985 (B) baseline differences connecting the six common stations RGOB, POTS, WETT, GRAZ, ZIMM, and MATE. Azimuth N. 19 $9^{\circ}$. (N. $7^{\circ}$ E.) of maximum contraction $-5.7 \times 10^{-7}\left(-2.1 \times 10^{-7}\right)$ for the period 1985-1984 (1986-1985). Taken from Katsambalos and others (1989).

following resolution: "In view of the unprecedented increase in population in the developing nations and the apparent concentration of much of this population in urban centers within regions of seismic risk, we recommend the implementation of geodetic networks with a scale and distribution appropriate to characterizing earthquake risk in these nations."

Global tomography, convection, stress, and geochemistry

ICL is sponsoring the Federation of Global Digital Seismic Networks (FGDSN) because the establishment of a network of seismic broadband stations is a precondition for the improvement of seismic tomography. Tomography reveals not only lateral heterogeneities, "hot" and "cool" regions of the convective mantle, but it leads to estimates of geoid undulation, plate velocities, and lithospheric stresses (Anderson and Dziewonski, 1984). An important factor for the evolution of tomographic heterogeneities is the dating of geochemical reservoirs.

\section{PALEOMAP PROJECT}

The PALEOMAP project (Carroll, 1989), under the leadership of Chris Scotese (USA), is one of the typical key projects of the ILP. It maps the evolution of the surface of the Earth, including the drift of the continents over the past $600 \mathrm{~m}$.y., by using ship and satellite data. The goal is to produce a global digital data base (Scotese, in press).

\section{Continental rifting}

Continental rifting is one of the intraplate processes that takes place at the beginning of continental breakup in plate tectonics, although it is not yet fully understood. The duration of the rifting stage is highly variable, but the level of rift-induced volcanism appears to be related to the rate of strain. Multiple mechanisms for crustal attenuation are lithospheric stretching (simple and pure shear), physical and chemical processes such as upward displacement of the crust-mantle boundary and injection of asthenospheric melt, and small-scale convection that causes ductile, lateral transfer of lower crustal material.

The observation and analysis of teleseismic travel anomalies provide important constraints on the evolution of rifting. This type of survey in the Kenya rift during the Kenya Rift International Seismic Project (KRISP) (Dahlheim and others, 1989), in combination with gravity data, allows us to estimate the degree of partial melting involved in the upper mantle during the rifting process.
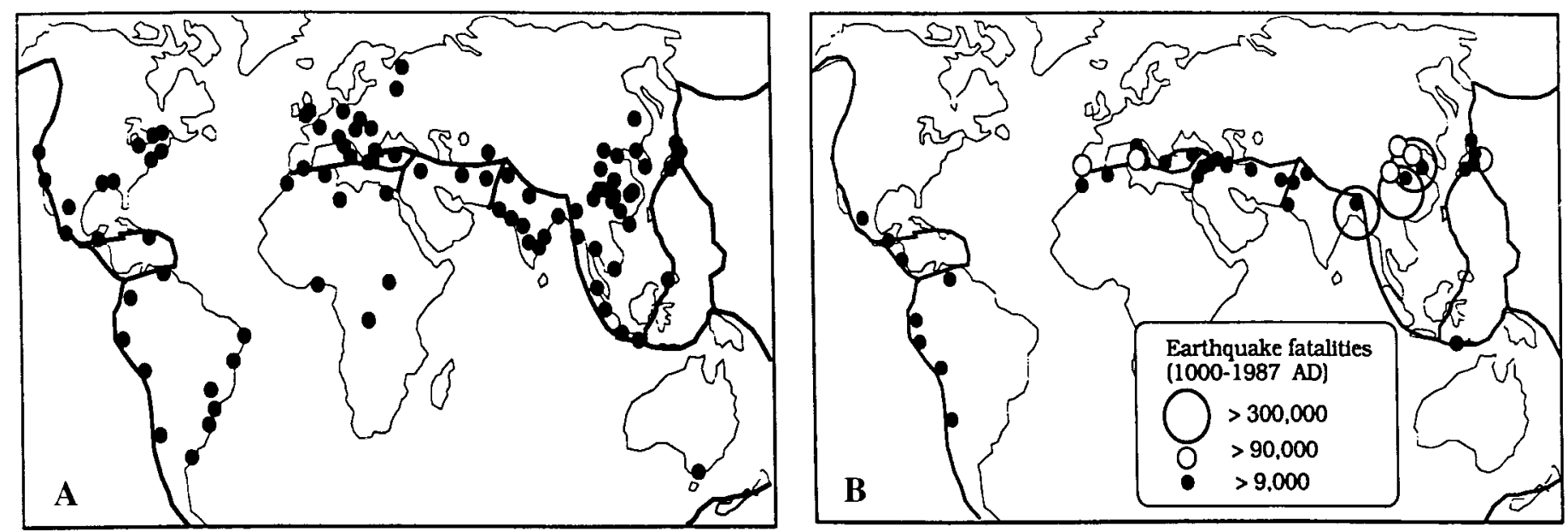

Figure 5. - World map showing the distribution of cities that have a projected population of 2 million people or more for the year 2000 (A). Bold lines represent convergent or strike-slip boundaries. World map showing the distribution of earthquakes in the past 1,000 years in which over 9,000 people have died (B). Most such disasters have occurred where cities coincide with plate boundaries (Bilham, 1988). 
Table 4. - ICL special projects on hazard mitigation and relation to International Decade for Natural Disaster Reduction

\begin{tabular}{|c|c|}
\hline Number & Project (coordinator) \\
\hline \multirow[t]{3}{*}{$\mathrm{CC}-1$} & Paleoflood hydrology (V.R. Baker). \\
\hline & $\begin{array}{l}\text { Multidisciplinary studies of selected high-risk volcanoes with emphasis } \\
\text { on collateral hazards (G. Heiken). }\end{array}$ \\
\hline & $\begin{array}{l}\text { Probabilistic approach to geological hazards (K.J. Coppersmith, C.G. } \\
\text { Newhall). }\end{array}$ \\
\hline
\end{tabular}

WG-1 . World map of active faults (V.G. Trifonov with A. Gvishiani/CC-5). Great earthquakes of the late Holocene (R. Yeats).

Application of space geodesy to global seismic hazards (R. Bilham, S. Zerbini).

WG-3 . World Stress Map (M.L. Zoback).

$\mathrm{CC}-3$. . Transects through hazardous regions in developing countries $(\mathrm{H}$. Gupta with J. Monger/CC-7).

Seismology and earth sciences in Africa (H. Gupta with IASPEI/ Unesco).

$\mathrm{CC}-4$. . Continental drilling in hazardous zones (M.D. Zoback).

CC-5... Neotectonic regionalization of the globe and identification of earthquake-prone areas (A. Gvishiani with V.G. Trifonov/ WG-1).

$\mathrm{CC}-7$. . Global Geoscience Transects through hazardous regions (J. Monger with H. Gupta/CC-3).

\section{ICL special projects}

ICL's terms of reference require close association with the subjects of hazard mitigation (table 4) and, therefore, also a close relationship with the International Decade for Natural Disaster Reduction (IDNDR). Also, Working Group 5, "Paleoenvironmental Evolution of the Oceans and Atmosphere," has an especially close relationship with the International Geosphere-Biosphere Programme (IGBP). Ocean basins are the sinks of the debris eroded from the surrounding continents. The sedimentation in the North Atlantic Ocean basin has changed drastically through the past $140 \mathrm{~m} . \mathrm{y}$. The sedimentation pulses are assumed to represent major revolutions of the erosional regime of the surrounding continents in response to global climate changes during the Cenozoic (Joern Thiede, oral communication).

A special concern of the ICL is the strengthening of the geosciences in the developing countries. A number of projects are directly related to this issue (table 5). The experience of the ICL is that the closest contacts with the earth scientists in developing countries come about when the scientists are actually involved in the projects. The best example of this is the Global Geoscience Transects project in which earth scientists from South America, Africa, PRC, and other develop-

\section{Table 5. - ICL special projects on geosciences in developing} countries

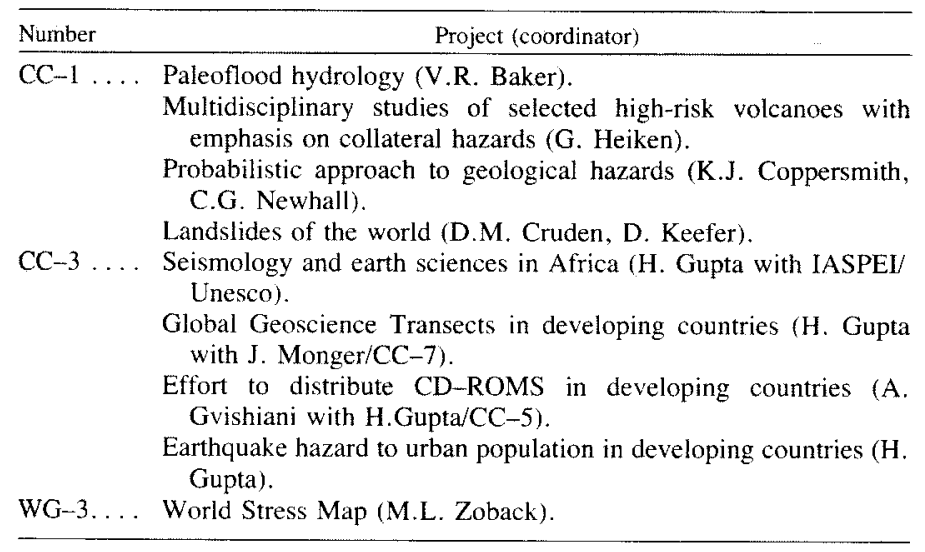

Table 6. - ICL special projects in relation to the applied sciences

\begin{tabular}{|c|c|}
\hline Number & Project (coordinator) \\
\hline $\mathrm{CC}-2$. & $\begin{array}{l}\text { Deep seismic and sedimentary basins (C. Bois). } \\
\text { Heat sources in time and space (H.J. Neugebauer). }\end{array}$ \\
\hline & Multisensor data integration for resource assessment (G.W. Hill) \\
\hline $\mathrm{CC}-4$. & Deep continental drilling (M.D. Zoback). \\
\hline WG-3 & World Stress Map (M.L. Zoback). \\
\hline WG-6 & $\begin{array}{l}\text { Reflection survey of the continental crust (A. Green). } \\
\text { Lower crust (R. Meissner with N. Arndt/WG-2c). }\end{array}$ \\
\hline
\end{tabular}

ing countries are striving vigorously for the completion of transects in their own countries. In addition, the ICL has expanded its work with the applied sciences through a number of projects (table 6).

\section{Conclusions}

\section{Impact of high technology on solid Earth sciences}

The solid Earth sciences have begun to enter a new age of exploration of the lithosphere. Scientists are applying highly sophisticated tools to the investigation of the crystalline lithosphere. These tools range from satellites to ground-based data acquisition systems both in the field and in laboratories, as well as simulation and modeling under controlled conditions in the laboratory and on supercomputers.

We are on the threshold of a new model of the lithosphere that includes additional elements such as material properties, stress and strain fields, mass transport, and temperature. We will have to develop new methods for understanding this highly complex, nonlinear system in order to be prepared also for hazard mitigation and protection of natural resources.

\section{Interdisciplinary and international application}

Characteristically, many scientific findings today result from interdisciplinary research efforts. Because of the diversity and separation of the earth sciences, we are running into a dilemma. The developments in the various disciplines come so quickly that there is a new danger that these disciplines are loosing sight of one another. One example involves the satellite missions in the field of solid Earth sciences. Launchings have to be decided 10 years in advance, and the users for these missions have to be defined today. We. the users, frequently do not even anticipate the possibilities that lie ahead of us. Therefore. the solid Earth sciences may lose out in the competition for priorities in the satellite platforms as a result of our lack of awareness.

We need to know that the GPS and satellite-based Global Laser Ranging System (GLRS) are not just advanced geodetic tools but that they will lead the earth sciences as a whole into the age of real-time tectonics, which will revolutionize our ability to mitigate hazards and to model the Earth's interior. The same is true for other sophisticated tools. Therefore, in planning satellite missions or other highly technical applications, the solid Earth sciences should be viewed as a whole, just as we must view the Earth as a system. Are we really recognizing the challenges that face the earth sciences?

A new gap within the solid Earth science disciplines is rapidly developing, and it might affect the future of our science much more severely than has the gap our disciplines have endured for centuries. If we do not support our fellow geodesists in their missions. these missions will not be flown and the funds will be diverted to other fields of science where a greater consensus exists. This will degrade earth 
science as a whole. We must reach a consensus that these highly technical experiments are necessary if the solid Earth sciences want to travel to new frontiers.

Interdisciplinary research is not just a love story, a romantic affair between disciplines or Unions, but it is a question of survival in the struggle for the future investigation of our planet. Indeed, it is a question of our mission to planet Earth. Therefore, the primary goals of the International Lithosphere Program are to define, to initiate, and to support interdisciplinary research at the forefront of the earth sciences. This is precisely what the International Lithosphere Program represents.

\section{References}

Anderson, D.L., and Dziewonski, A.M., 1984, Seismic tomography: Scientific American, v. 251, p. 60-68.

Bilham, R., 1988, Earthquakes and urban growth: Nature (London), v. 336, p. $625-626$.

Bilham, R., Yeats, R., and Zerbini, S., 1989, Space geodesy and the global forecast of earthquakes: EOS (American Geophysical Union Transactions), v. 70 , p. 65,73 .

Carroll, L.P., 1989, The PALEOMAP project: The World \& I, March, p. 284-291.

Dahlheim, H.A., Davis, P., and Achauer, U., 1989, Teleseismic investigation of the East African Rift, Kenya: Journal of African Earth Sciences, v. 8, special issue, p. 461-470.

Galson, D.A., and Mueller, Stephan, 1987. The European Geotraverse (EGT) project: A progress report, in Fuchs, K., and Froidevaux, C., eds., Composition, structure and dynamics of the lithosphereasthenosphere system: American Geophysical Union Geodynamics Series, v. 16, p. $253-272$.

Goetze, H.-J., Lahmeyer, B., Schmidt, S., Strunk, S., and Araneda, M., 1990, Central Andes gravity data base: EOS (American Geophysical Union Transactions), v. 71, p. 401, 406-407.

Holbrook, W.S., Gajewski, D., Krammer, A., and Prodehl, C., 1988, An interpretation of wide-angle compressional and shear wave data in southwest Germany: Poisson's ratio and petrological implications: Journal of Geophysical Research, v. 93B, p. 12081-12106.

Katsambalos, E., Livieratos, E., Marsella, M., and Zerbini, S., 1989. European Laser Station coordinates through a free adjustment of SLRbaselines: WEGNER/MEDLAS Conference, 4th. Scheveningen, The Netherlands, 7-9 June 1989.

Klemperer, S.L., 1987, A relation between continental heat flow and the seismic reflectivity of the lower crust: Journal of Geophysics, v. 61, p. $1-11$.

Lueschen, E., Wenzel, F., Sandmeier, K.-J., Menges, D., Ruhl, Th., Stiller, M., Janoth, W., Keller, F., Sollner, W., Thomas, R., Krohe, A., Stenger, R., Fuchs, K., Wilhelm, H., and Eisbacher, G., 1987, Nearvertical and wide-angle seismic surveys in the Black Forest, SW Germany: Journal of Geophysics, v. 62, p. 1-30.

McGeary, S., and Warner, M.R., 1985, Seismic profiling the continental lithosphere: Nature (London), v. 317, p. 795-797.

Minster, J.B., and Jordan, T.H., 1978, Present-day plate motions: Journal of Geophysical Research, v. 83, p. 5331-5354.

Monger, J.W.H., 1986, The Global Geoscience Transects project: Episodes, v. 9 , p. $217-222$.

1989, Global project traces structural evolution: Geotimes, v. 34, p. 11-13.

Oliver, Jack, 1986, A global perspective on seismic reflection profiling of the continental crust, in Barazangi, Muawia, and others, eds., Reflection seismology: A global perspective: American Geophysical Union Geodynamics Series, v. 13, p. 1-3.

Percival, J.A., and Berry, M.J., 1987, The lower crust of the continents, in Fuchs, K., and Froidevaux, C., eds., Composition, structure and dynamics of the lithosphere-asthenosphere system: American Geophysical Union Geodynamics Series, v. 16, p. 33-59.

Reutter, K.-J., Giese, P., Goetze, H.-J., Scheuber, E., Schwab, K., Schwarz, G., and Wigger, P., 1988. Structures and crustal development of the Central Andes between $21^{\circ}$ and $25^{\circ} \mathrm{S}$., in Bahlburg, H.,
Breitkreuz, Ch., and Giese, P., eds., The southern central Andes: Berlin. Springer-Verlag, Lecture Notes in Earth Sciences, v. 17, p. 231-261.

Rudnick, R.L., Arndt, N.T., and Presper, T., 1988, Geochemistry of granulite terrains and granulite xenoliths: Relevance to present day lower crustal composition: Terra Cognita, v. 8, p. 271.

Scotese, C.R., ed., in press, The atlas of Phanerozoic plate tectonic reconstructions, International Lithosphere Program PALEOMAP project: Washington, D.C., American Geophysical Union.

Smith, D.E., Christodoulidis, D.C., Kolenkiewicz, Ronald, Dunn, P.J., Klosko, S.M., Torrence, M.H., Fricke, S., and Blackwell, S.. 1985. A global geodetic reference frame from LAGEOS ranging: Journal of Geophysical Research, v. 90B, p. 9221-9233.

Stewart, D.B., 1989, Digital geologic data sets: The example of the QuebecMaine-Gulf of Maine Global Geoscience Transect, in United States Geological Survey yearbook, fiscal year 1988: Washington, D.C., U.S. Government Printing Office, p. 58-61.

Stewart, D.B., Unger, J.D., Wright, B.E., Philips, J.D., Liberty, L.M., Spencer, C.P., Charlesworth, P., Hutchinson, D.R., Klitgord, K.D., Luetgert, J.H., and Bothner, W.A., 1989, Digitization of QuebecMaine-Gulf of Maine Global Geosciences Transect [abstract]: International Geological Congress, 28th, Washington, D.C., 1989. Abstracts, v. 3, p. 181.

Wenzel, F., Sandmeier, K.-J., and Waelde, W., 1987. Properties of the lower crust from modeling refraction and reflection data: Journal of Geophysical Research, v. 92B, p. 11575-11583.

Zoback, M.D., Elders, W.A., Schmus, W.R. van, and Younker, L.W., 1988. The role of continental scientific drilling in modern earth sciences, scientific rationale and plan for the 1990's, in Workshop on Continental Scientific Drilling, Stanford, California, 1988, Report: Stanford, California, USA, Stanford University, $151 \mathrm{p}$.

Zoback, M.D., Silver, L.T., Henyey, T., and Thatcher, W., 1988, The Cajon Pass scientific drilling experiment: Overview of phase 1: Geophysical Research Letters, v. 15, special issue, p. 933-936.

Zoback, M.D., Zoback, M.L., Mount, V.S., Suppe, J., Eaton, J.P., Healy, J.H., Oppenheimer, D., Reasenberg, P., Jones, L., Raleigh, C.B., Wong, I.G., Scotti, O., and Wentworth, C., 1987, New evidence on the state of stress of the San Andreas fault system: Science, v. 238, p. 1195-1211.

Zoback, M.L., Zoback M.D., Adams, J., Assumpcao, M., Bell, S., Bergmann, E.A., Bluemling, P., Denham, D., Ding, J., Fuchs, K., Gregersen, S., Gupta, H.K., Jacob, K., Knoll, P., Magee, M., Mercier, J.L., Mueller, B.C., Paquin, C., Rajendran, K., Stephanson, O., Suter, M., Udias, A.. Xu, Z.H., and Zhizhin, M.. 1989. Global patterns of tectonic stress: Nature (London), v. 341, p. 291-298. $\square$

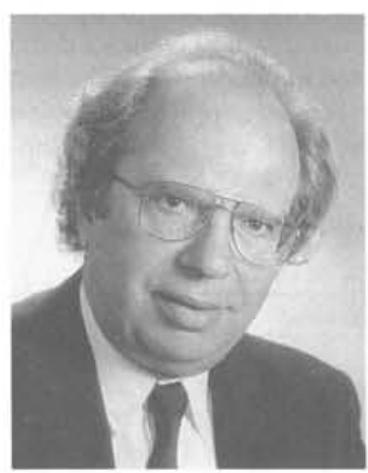

Karl Fuchs, born in 1932 at Stettin, Poland, is Professor of Geophysics at Karlsruhe University in Germany. From 1985 to 1990, he was President of the ICSU Inter-Union Commission on the Lithosphere. His main research interests are deep seismic probing of the lithosphere-asthenosphere system and implications for physical properties and composition, in particular the lower crust of the continents and the upper mantle. He is actively engaged in the investigation of continental rifting, stress in the lithosphere, continental deep drilling, and numerical modeling of wave propagation. He is a Fellow of the American Geophysical Union and of the Geological Society of London, as well as a member of the Academia Europaea and of the Heidelberg Academy of Science. 